Euskal ikerketen aldizkaria | Revue d'études basques |

Revista de estudios vascos | Basque studies review

$9 \mid 2004$

Numéro IX

\title{
Juan Antonio Mogelen Peru Abarka : marko narratiboa marko zientifikoaren mugak hautsiz
}

\author{
Ana Toledo Lezeta
}

\section{OpenEdition}

\section{Journals}

Édition électronique

URL : http://journals.openedition.org/lapurdum/875

DOI : 10.4000/lapurdum.875

ISSN : 1965-0655

Éditeur

IKER

Édition imprimée

Date de publication : 1 novembre 2004

Pagination : 283-297

ISBN : 2-68781-376-X

ISSN : $1273-3830$

Référence électronique

Ana Toledo Lezeta, « Juan Antonio Mogelen Peru Abarka : marko narratiboa marko zientifikoaren mugak hautsiz », Lapurdum [Linean], 9 | 2004, Sarean emana----an 01 mars 2009, kontsultatu 01 mai 2019. URL : http://journals.openedition.org/lapurdum/875; DOI : 10.4000/lapurdum.875 


\title{
Juan Antonio Mogelen Peru Abarka : marko narratiboa marko zientifikoaren mugak hautsiz
}

\author{
Ana TOLEDO LEZETA \\ Deustuko Unibertsitatea
}

\begin{abstract}
Marko narratiboa eta marko zientifikoa elkarturik ibiltzea ez da usuena letren barrutian, ez iragandako garaietan, are gutxiago, gaur egunean. Elkarketarik usuena ez izan arren, Juan Antonio Mogelen Peru Abarka idazlana zientziarekin harremanean atzemateak izan du lekurik : aski da idazlan horri buruz egin diren azterketetara jotzea harreman horren berri izateko. Hala zioen, esaterako, Jon Kortazarrek :
\end{abstract}

"Mogelek ere literatura eta zientzien arteko lotura zaintzen du. Baina, bere kasuan, zientzia filologia dugu". ${ }^{1}$

Helburu linguistikoa duela gauza jakina da. Aspaldi adierazi zuen $\mathrm{M}^{\mathrm{a}}$ Luisa Diez Ezkerrak funtzio metalinguistikoa nagusitzen zela testuan ${ }^{2}$; izan ere, kodea bera du erdigune, idazteko darabilen kodea bera : kodea goretsi, aztertu, prestigioa eman.

Testuaren azterketak ondorio horietara eraman zituen. Ukaezina da, nire ustez, ondorio horietara heltzeko oinarririk badagoela Peru Abarkan. Are gehiago jakin dakigunean zientziek zorroztasunean eta zehaztasunean irabaziz joan direla gure egunetara heldu ahala eta aurreko mendetako idazlan zientifikoei ez dagoela eskatzerik egungoei ezartzen zaizkien eskakizun estuak. Mogelek bere garaian praktikatzen zen zientzia modua dakar, bere garaiko ideia linguistikoetan oinarritutako zientzia linguistikoa, hain zuzen ere. Honela, Peru Abarka hizkuntza aztergai duen idazlan zientifikotzat jo daiteke.

Asmo jakin bati erantzun nahi dio kodea arretagune hartzean : jende ikasiak egiten duen erabileran eragin. Asmoa betetzeko kodea aztertu eta goretsiko du. Zentzurik osoenean egiten da euskararen apologia ; batetik, hizkuntza goratzen du eta bestetik, egin zaizkion salaketei aurre egiten die, salaketa horiek nori zuzendu behar zaizkion adieraziz : hitz zientifikoen gabeziagatik hiztegi urrikoa izatea egotzi bazaio euskarari, hutsune honen erantzunkizuna ez dago hizkuntzan, baizik eta berau lantzeaz arduratu ez direnengan. Euskararen perfekzioa erabatekoa ez bada, berau lantzeaz arduratu ez direnei egotzi behar zaie ; ez hizkuntzari : horra hor hiztegi aberatsa ez izatearen erantzuleak.

1 - KORTAZAR, J. (1982) : "Mogel eta bere garaia", ASJU, XVI, 48. or.

2 - A Zelaietak aipatua. Ikus ZELAIETA, A (1979) : Peru Abarcaren berrirakurtzea, Kriselu, Donostia, 79.or. 
Juan Antonio Mogelen Peru Abarkak badu aitzindaririk XVIII. mendean ; izan ere, ukan zuen aurrekaririk, nola euskararen erabateko perfekzioa eragotzi duten kausak seinalatzerakoan, ${ }^{3}$ hala perfekzio hori erakusteko eginkizunean. Urrutirago joan gabe, kodea goresteko, aztertzeko eta beronen erabileran eragiteko idatzi zituen Larramendik El imposible vencido. Arte de la lengua Vascongada (1729) edo Diccionario Trilingüe. Castellano, Bascuence y Latín (1745).

Peru Abarka XIX. mendearen azken laurdenean argitaratutako obra izanagatik, XVIII. mendean barrena hazitako eta hezitako lumak, Juan Antonio Mogelek (1745-1804), idatzia ez-ezik, mende-mugaren inguruan amaitutako idazlana da : Vargas Poncerekin izan zuen eskutitz-harremanetik ondoriozta daitekeenez, 1802an egina zuen.

Larramendi eta Mogel hizkuntzaren egoeraren diagnosian bat etortzeaz gainera, egoera horri aurre egiteko idaztekintzara igaro ziren. Idaztekintza honetan testu desberdinak bideratu zituzten ; izan ere, batak hiztegi-gramatikak jo zituen eraginkorren bezala, besteak, berriz, autua. Autuaren aukerak zigilu berezia ematen dio kodea bera arretagune izan duten idazlanen artean.

Biak bat datoz helburuak ezartzerakoan. Mogelek irakurle bizkaitarrari zuzentzen dion hitzaurrean azaltzen duenez :

"he juzgado hacer un gran servicio a la patria sacando al teatro público...

Baita Larramendik ere, nahiz eta ez izan bere idazlan linguistikoak egitera bultzatu zuen arrazoi bakarra. Gramatikari egin hitzaurrean dioenez :

"El impulso, que me hizo empeñar en estudio tan espinoso, no fue sola la pasion de ennoblecer, è ilustrar nuestra Lengua, y por este lado acreditar à la Patria. Fue otro mayor, y mas propio de mi carácter, y consiste en el gran bien, y utilidad, que espero se ha de seguir à todo el País del Bascuenze. Allí es necessaria esta Lengua, sirviendo muy poco el Romance para el comun de la gente : por otra parte se ignoran sus primores, frases, construccion varia, y oportuna, ò ay muy corta noticia desto. De donde nace, que comunmente no se predica con la eloquentia, y eficacia, de que es capaz la Lengua ; que son pocos los que se aplican à este ministerio ; que otros se amedrentan con la dificultad; que no se explica, como se debiera, la Doctrina Christiana ; que no ay libros, que sirvan para estos importantes ministerios; que nadie se atreve à traducirlos de otra Lengua. Pero aviendo ya Arte con methodo, y reglas fixas, y luego Diccionario, que siendo Dios servido se dará tambien à la luz publica, se ocurre à estos inconvenientes, y podrán facilmente los Predicadores, Misioneros, Señores Curas, y otros Zelosos del bien de las almas, cumplir con sus obligaciones". 5

3 - “Los Bascongados no parece que han hecho aprecio della, ò à lo menos no le han explicado. Salen de su País, y hacen estudio de olvidarla ; ni escriben, ni quieren siquiera escribir en su Lengua una Carta. Dentro del País se destierran quantos medios pudieran conducir para conservarla y descubrir sus primores" LARRAMENDI, Manuel de (1745) : Diccionario Trilingue del Castellano, Bascuence, y Latin, I, Bartholomè Riesgo y Montero, San Sebastian, LJV. or. Honela zekusan Kardaberazek 1761ean latin-grekeren eta euskararen arteko aldea : "Izcunde estimatu oiec biac ere beren oreñac edo tachac bacituzten len ; baña güero, ascojaquiñen artean oi dana, egunoro ta obeto poliquitu ta apañduaz biac joan dira. (...).

Gure eusquerac bazter oietan orrelaco guizaseme andien patu onic izan eztu. Baña latin ta griegoac ascojaquiñen dicha ta gloria ori izan badute ; bere modura maravilla chiquiago ezta, baicic miragarrizco prodigio andiago, nola eusquera soll soll, bacarric, edo nic eztaquit nola, biciric aimbeste seculetan egon dan ta dagoen ; añ berez ta beregan, añ argui ta garbi, bere erio ta arerio gucien damu gorri gaistoan badere. Alere, asco eguiequi eusquera galdu da. Baña ori ezta euscararen, ezpada euscaldunen desonra ; bada oiec poliquitu, apañdu ta edertu bearrean, lotsaric gabe berac beren naguitasunez itsustu, larrutu ta deseguin izan dute". ALTUNA, Patxi . ZULAIKA, Esther (Ed.) (2004) : Aita Agustin Kardaberaz. Eusquera ren berri onac, Euskaltzaindia, Bilbo, 24. or. 4 - AREJITA, Adolfo (Ed.) (1990) : Juan Antonio Mogel. Peru Abarka, Kriselu, Donostia, 25. or. Aurrerantzean egingo diren aipamen guztiak edizio honetatik jasoko dira.

5 - LARRAMENDI, Manuel de (1729) : El imposible vencido. Arte de la Lengua Bascongada, Hordago Publikapenak, Donostia, (edizio faksimila), hitzaurrea orrialdeak zenbatu gabe. 
Hiztegiaren hasieran ageri den eskaintzan gramatikaren hitzaurrean azaldutako helburu berbera erakusten du. ${ }^{6}$

Helburu pastorala da Larramendiren idazlan hauen azken jomuga. Elizgizonek beren predikuetan egiten duten hizkuntzaren erabilera aldatu nahi du. Aberriari zerbitzua egiteak sustatzen badu ere, batik bat apaizak ditu gogoan : hauek sermoietan darabilten erdara edo euskara traketsa, euskara duinagatik ordezkatu nahi du. Horretarako bide bezala gramatika eta hiztegia ikusi zituen.

Barruti zabalagoan kokatzen du Mogelek bere idazlanaren hartzailea. Irakurle bizkaitarrari zuzendutako hitzaurrean bertan zehazten du :

"Estos diálogos no se dirigen a la instrucción de la juventud bascongada, sino a la de los que son tenidos por muy literatos. Parece algo extravagante el título de la obra ; pero no lo será a quien atentamente considera que un rústico bascongado puede ser doctor y maestro de su lengua, y ser catedrático de ella, llamando a su escuela de las montañas a clérigos, frailes, caballeros, y demás que no se han fatigado en meditar el artificio curioso, ni las saladas expresiones de dicho idioma" (25. or.).

Jende ikasiarentzat idazten dute biek, nahiz eta Larramendik eremu horren barnean ikasi jakin batzuk izan gogoan. Abiapuntuan bat datozen idazleak -jende ikasiak hizkuntzaz egiten duen erabileran eragin- helburua lortzeko bidean aldendu ziren. Larramendik hiztegia eta gramatika hautatu zituen : kodean jarri zuen arretagune soila, kode eredugarria erabiltzeko bitartekoak eskura jartzean, hain justu. Idazlan linguistiko soilak dira. Mogelen ikasgaia, Larramendirena bezala, linguistikoa izatean, arruntagoa zatekeen honek baliatutako bideren bati heltzea. Peru Abarkan lantzen den hizkuntza alderdi nagusia ikusita, hiztegia izan zitekeen, ikasgaia emateko bitartekoa, baina, hiztegia baztertu eta autura jo zuen. Ez zen izan oharkabean egindako aukera ; izan ere, autuari egin hitzaurrean bertan aitortzen duenez, gabezia nabarmenak atzematen ditu hiztegigintzan : bizkaitarrek ez dute batere, ezta gipuzkoarrek ere, euskal hitzaren sarrera abiapuntu, honen erdal ordainik emango duenik. Beraz, hiztegigintza urria izanik, osa zezakeen esparru hau. Haatik, jakinaren gainean, beste liburu-mota bat egitea erabaki zuen :

“La lectura de buenos libros instruye mucho más que un gran diccionario (34. or.)".

Euskararen apologia egiteko eta euskara eredugarria erakusteko "liburu ona" zuen biderik egokiena.

Peru Abarka ren hitzaurrean behin eta berriz isurtzen da "instruir" hitza. Nola Mogelek, hala Larramendik irakastea dute jomuga. Hiztegiak edo gramatikak bereberea duten ezaugarria da, baita autuak ere. Baina, autuak ezaugarri horri besteren bat eransten dio, Mogelen idazlanaren hitzaurretik bertatik ondoriozta daitekeenez : "instruir" hitzarekin batera eta beroni loturik erakargarri eta josta ri

6 - "no es esto lo que mas me alentò à luchar contra las dificultades de esta Obra. Mi principal impulso fue la persuasion, ò la esperanza de que avia de conducir, no solo para la gloria de V. S., sino aun mas para la de Dios, que resulta del aprovechamiento de las almas. Muchos Castellanos, y muchos Bascongados, habilitados fuera del Paìs para el Pulpito, y el Confessonario, especialmente en mi Religion, y en su Provincia de Castilla, vienen á Guipuzcoa, y Bizcaya, sin saber el Bascuence, ò por no haverle antes aprendido, ò por tenerle yà olvidado con el no uso de muchos años. Todos estos se hallan obligados à tener casi ociosos sus talentos, sin poder emplearlos en beneficio universal de las almas, mientras no aprenden el Bascuence : y es mui dificultoso aprenderle en una edad adulta, sin el socorro de un Diccionario. Esta dificultad, que hasta aquí ha desalentado à muchos, à pesar de su inclinacion, y de su celo, espero se suavizarà en adelante con el Diccionario". LARRAMENDI, Manuel de (1745) : Dicciona rio Trilingue del Castellano, Bascuence, y La tin, I, eskaintzako orrialdeak zenbatu gabe. 
hitzak erabiltzen dira. Autuak modu erakargarrian irakasten du. Horregatik, gaztejendeak nekerik gabe latina ikas zezan, Juan Luis Vives, "se valió para el efecto del atractivo que trae de sí el diálogo" (25. or.). Mogelek "A ejemplo de tan grande hombre en la república literaria" (25. or.) idatziko ditu bereak.

Mogelek erabilgarritasuna eta erakargarritasuna uztartu nahi ditu. Hizkuntzaren erabilera eredugarria azaltzea du helburu. Alabaina, ez du aski helburu hori betetzearekin, ez du aski eredu linguistiko bat hartzaile ikasiaren esku jartzearekin ; eredua hartzaile horren esku jartzeaz gainera, eredu horretara erakartzea du jomuga. Funtzio metalinguistikoa du nagusi, baina kode eredugarria erakustearekin ez du nahiko : hartzaile jakin baten borondatea irabazi nahi du. Borondate hori irabazteko, ahalik eta modurik erosoenean eman behar du ikasgaia : elkarrizketan ikusi zuen bidea. Ordu arte euskal literaturan landu gabe zegoen genero batera ${ }^{7}$ jotzen du eta, neurri batean, jarraibide bihurtzen ; izan ere, XIX. mendean zehar, Peru Abarka kopiak bide zabaltzen ari zen bitartean, Agustin Pascual Iturriagak ${ }^{8}$ edo Jean Duvoisinek ${ }^{9}$ erabiliko dute. Euskal idazleak historikoki xede didaktikoarekin idatzi duen arren, beste adierazpen-modu batzuk gogokoago izan ditu bere irakatsiak emateko, jorratzen den gaian aditu den maisuaren eta gai horretan ezjakina izanik ikasteko edo aholkua jasotzeko prest dagoen ikaslearen arteko solasak sustrai zaharrak eta sakonak izanagatik literaturan.

Mogelek, Errenazimentuko tradizio humanistaren arrastoan kokatuz, ereduekiko begirunea erakusten du. Hitzaurrean aitortzen duenez, Juan Luis Vivesengan aurkitu zuen eredua, honen "aplaudida obra del ejercicio latina"n ediren baitzuen bere egitekorako behar zuen generoa : autua zen hizkuntza bat modu erakargarrian irakasteko bitartekorik egokiena.

Ereduekiko begirunea ez da agortzen Vivesek Errenazimentu garaian eginiko elkarrizketak jarraibide hartzean ; izan ere, Peru Abarka hizkuntza eredu baten aurkezpena eta hobespena da. Vivesek gazteriari irakatsi nahi dion hizkuntza -latinalandua da, gramatikaduna, arautua... Ez daude pare-parean Vivesek irakatsi zuen hizkuntza eta Mogelek irakatsi nahi duena : idatziz gutxi landu dena, irakas geletatik kanpo dagoena, hainbat jende ikasik mesprezatua, arautu gabea... Bada egitekorik euskara latinaren edo inguratzen duten erdaren parean jartzeko. Euskara gramatikaren iragazitik iragaztea eta erdal hiztegiko hitz guztiei euskal ordaina jartzea izan zen Larramendiren ekarria. Tresna hauek eskuratu zizkien elizgizonei beren euskara-maila hobetu zezaten. Besterik da Mogelen aukera : hizkuntza eredu bat eman. Baserrian aurkitu zuen asebetetzen zuen eredua. Idazlanari ipini zion izenburua jarraituz, "El doctor Peru Abarca. Catedrático de la Lengua Bascongada en la Universidad de Basarte" da euskara eredugarria darabilena. XVIII-XIX. mendeen arteko mugan Mogelek Peru aurkezten du maisu; honen aurretik, ordea, ereduen itzalean babestu zen XVIII. mendeak aurkeztua zuen beste maisu bat : Axular. Ez Mogelek bezala, autua baliatuz, baina Joanes Etxeberrik, esaterako, argitaratzera heldu ez zen Escuararen Hatsapenac apologian, bide-erakuslea aukeratzean ez zuen baserrira begiratu, Axularrengana baino : Axularrek Geron (1643) erabilitako prosan aurkitu zuen eredua.

Honela bada, ez zen nahitaezko eta halabeharrezko baserrira joatea euskaraeredu bat proposatzeko. Dena den, euskara-baserritarra lotura ez zen arrotza Peru

7 - Micoletak bere Modo breve de aprender la lengua vizcaina ren amaieran elkarrizketa labur batzuk jasotzen zituen, baina idazlan hau ez zen argitaratu XIX. mendearen bukaera arte.

8 - Diálogos basco-castella nos para la sescuelas de primeras letras de Guipúzcoa, Hernani, 1842.

9 - Laborantzako liburua edo Bi aita semeren solasak laborantzaren gainean, Andre Lamaigneren moldiztegian, Bayonan, 1858. 
Abarka idatzi aurretik. Aita Kardaberazek, adibidez, baserritarrarengan zekusan euskararekiko atxikimendurik handiena :

"gure baserrietan gende prestuac dirauten artean, euscarac iraungo du. Esan oi dana : oiei lepoa ebaqui edo bicia quendu gabe, euscara ecin utci edo quendu diteque". ${ }^{10}$

Euskara hizkuntza garbia eta aberatsa dela frogatu behar duen Mogelek basora jo zuen, euskara jatorrian zuen garbitasunean gorde duen basora, hain zuzen ere. Basoak hazi eta hezi duen pertsonaia batengan aurkitu zuen maisua : "un rústico que no ha puesto pies en la escuela de las primeras letras ; un solitario que no ha salido de los bosques del bascuence, que no sabe una palabra de otro idioma" (26. or.). Nahasketa oro saihestuz, euskara bere jatorrizko garbitasunean gorde duen baserritarrari Peru Abarka izena eman zion. Euskararen katedratiko honentzat solaskide nagusia bilatzerakoan basoa utzi eta, kalera jo zuen bizargin ikasketak eginak zituen batengana : Maisu Juan. Hala, "liburu ona" egin zuen, beti ere, hiztegi batek baino gehiago irakasten duen "liburu on" bat.

Larramendik eta Mogelek ikasiei zuzendutako helburu linguistikodun idazlanak egin zituzten, baina bide desberdinak erabiliz, testu-mota desberdinak gauzatuz. Zorroztasun handiago edo txikiagoarekin biak zientziaz baliatu baziren ere, Mogelek, Larramendik ez bezala, fikziozko markoa hautatu zuen : leku-denborazko koordenada jakin batzuetan kokatutako pertsonaien esan eta ekintzen berri eman zuen. Gisa honetan jokatuz, marko narratibo txiki baten barnean garatzen diren elkarrizketak itxuratu zituen. Zientzia eta fikzioa nahastera jo zuen. Eragiketa honetatik erne zena ez zen zientzia soila : zientzia, bizimolde eta balore-sistema bati atxikia zetorren, gerora euskal kontaketak hobetsiko duen bizimolde eta baloresistemara uztartua, hain zuzen ere.

Mogelen Peru Abarka ez da idazlan zientifiko soila. Balorazio honen asmoa ez da darabilen zientzia-maila neurtzea, baizik eta jakintza linguistikoa emateko darabilen markoak idazlanari eransten diona azpimarratzea. Hizkuntza du aztergune, baina hizkuntzaren azterketa hori marko narratibo baten barnean garatzen da. Aztergunea ezin bereiz daiteke azterketa egiteko erabilitako markotik. Hortik gaurko jardunaldi honi jarritako izenburua : marko narratiboa marko zientifikoaren mugak hautsiz.

Abiapuntuan helburu linguistikoa duen arren, helburu linguistiko horri erantzuteko "liburu ona" moldatzean, hizkuntza eredu hutsa ematera mugatu gabe, bizimolde eta balore jakin batzuk atxiki zizkion hizkuntza ereduari. Peru Abarka baserritarraren eta Maisu Juan bizargin kaletarraren arteko aurkakotasunak hizkuntza ereduaren esparrua gainditu eta, munduan kokatzeko modu jakin bat ere adierazten $\mathrm{du}$. Solas horietan garaile ateratzen den ikuskera izango da euskal eleberrigintzan biziko den pertsonaia nagusiak bere egingo duena. Jesus Maria Lasagabasterrek zioen bezala,

“Mogel'en liburuak, bai egituragatik, baita ere gaiaren mailan aurkezten dizkigun elementu batzuegatik, baserri-bizitzaren gorespenetan oinarrituriko geroko ohiturazko-nobelarekin zer ikusi eta antz handiago du, egilearen beste idazlan linguistiko eta erlijiosoekin baino". ${ }^{11}$

Hizkuntza eredugarriari bizimolde eta balore-sistema eredugarria uztartzetik ernetzen den ikuskerak bizi-iraupen luze samarra eskuratuko du euskal letretan, XIX-XX. mendeen arteko mugan jaiotzen den euskal eleberrigintzak jasoko duelako

10 - op. cit. 24-25. orr.

11 - LASAGABASTER, J. M. : "Euskal-nobelaren gizarte-kondairaren oinharriak" in TOLEDO, A. (Ed.)

(2002) : Las literaturas de los vascos, Deustuko Unibertsitatea, Donostia, 85. or. 
lekukoa : Peru Abarkan itxura hartzen duen mundu-ikuskera izango du euskarri mende erdi luze batean. Txomin Agirreren Garoako (1912) Joanes pertsonaia nagusia hari mehe fin batek lotzen badu Perurekin, baita Peru Abarka idatzi eta mende eta erdira Eizagirreren Ekaitzpean (1948) eleberriko Xabier pertsonaia ere :

“Bai, ori ala izango da -dio Xabier'ek- bañan kaletar aundizki-alabei ere Malen'ek ezer zor ez diote, eta, berari esana dioten bezela, euskaldun zintzo ta zerbait dakien batentzat baserritar izatea izan liteken gauzik ederrena da, euskaltasuna, gure euzko-odola eta gure euzko-izaera guztia, garbi ta egokiena gordetzen dan tokia baserria dalako...". ${ }^{2}$

Mundu-ikuskera bakarra mende erdi luze batean, ez haatik, mende erdiko biziiraupen soila izan duena ; izan ere, XX. mendearen bigarren erdian euskal eleberrigintza eraberritzen duten eleberriek, ordu arteko homogenotasunarekin hautsi eta beste mundu-ikuskerarik ere adierazten badute, ez da Peru Abarkan itxuratzen hasten den horri amaiera jarriaz, baizik eta berarekin batera biziaz. Bestela esanda : Peru Abarkak giza talde baten mundu-ikuskera adierazten badu, badirudi, idazlan hori idatzi eta hurrengo mende eta erdi luzean, giza talde horren mundu-ikuskera bakarrik adierazi duela euskal fikziozko prosak. Euskal gizartea osatuz beste mundu-ikuskera bat zuen giza talderik egon bazen, honek ez zuen ikuskera hori adierazi fikziozko prosa bide, harik eta XX. mendearen bigarren erdia heltzen den arte : orduan hasiko da euskal fikziozko prosa mundu-ikuskeren aldi bereko existentzia adierazten.

Euskal kontaketa mundu idatzian lehen urratsak ematen hasten den urteetan $^{13}$ argitaratzen da Peru Abarka. XIX. mendearen azken herenean eleberri legez irakur daitezkeen lehen testuak itzultzen dituzte, ${ }^{14}$ lehen itzulpen horien argitalpenetik gutxira, 1879an, Donostiako euskal festek barneratzen zuten sariketa literarioak lehen leiendak bideratuko ditu. Urrats txiki eta urri hauek ematen ari diren unean ikusten du argia Peru Abarkak 1881ean. ${ }^{15}$ Argitaratze-data honen inguruan lantzen hasten den eta aurrerantzean XX. mendearen bigarren erdirarte bizi-iraupena izango duen euskal kontaketak izpiritu erromantikoa du euskarri. Izpiritu erromantikoan sustraiak dituen kontaketa leiendistiko-kostunbristaren ildoan kokatzen da. Leiendak edo gure ohituren gaineko idatziak eskatzen zituzten Donostiako euskal festak ; Bein da betiko (1893) leienda argitaratu zuen Resurreccion Maria Azkuek ; Antonio Truebaren El Judas de la Casa ren moldaketa Pachicu Cherren (1890)- egin zuen Antero Apaolazak; eleberri historikoa kaleratuz hasi zen Txomin Agirrek -Auñemendiko Lorea (1898)- ohiturazkoekin eman zion jarraipena bere eleberrigintzari, Kresa la (1906), Ga roa (1912)...

Ordurako, ordea, ia mende bat zeraman idatzita Peru Abarkak. Hala, XIX-XX. arteko mende-mugan hasten den ohiturazko eleberrietan goretsiko den

12 - EIZAGIRRE, J. (1948) : Eka itzpean. Ipuinberri, Editorial vasca Ekin, Buenos Aires, 149-150. orr.

13 - Gipuzkoako Foru Aldundiak, 2004ko otsailean, erosi berri zuen eskuizkribu bat eman zuen ezagutzera : Perez de Lazarragak XVI. mendearen 60. urteak aldera egindako poesiak eta artzain-eleberri bat jasotzen ditu. Aurkikuntza honek euskal kontaketa idatziaren sorrera hiru mendez aurreratzen du, baita literatur genero tradizionalak lantzen zituzten eskuizkribuak gehiago izan zitezkeela pentsatzeko bide eman ere. Alabaina, susmoak susmo, beste aurkikuntzarik ezean, euskal prosa narratiboaren sorreraren erakuskari isolatu legez gelditzen da Lazarragarena, konta-generoek jarraipen ezagunik ez izatean hurrengo hiru mendeetan. Honenbestez, XIX. mendearen azken heren arte itxaron behar da jarraikotasuna izango duten lehen urratsekin topo egiteko euskal kontaketa idatziaren barrutian.

14 - Ez dira asko, baina bada lekukotasunik : Gregorio Arruek Brabanteko Jenobebaren bizitzaz argitaratutako itzulpena (1868) eta J. B. Dasconagerreren Les échos du Pas de Roland jatorri duen Atheka gaitzeko oihartzunak (1870).

15 - Nahiz eta garaiko berrien arabera inprimatze-lan hori ez zen amaitu 1882arte. 
bizimoldearen eta defendatuko den balore-sistemaren aitzindari da. Honenbestez, Mogelen idazlanaren lokarriak bi norabideetan atzeman daitezke, dela lehenaldi hurbilari, dela geroaldiari begira : marko zientifikoak lotzen du XVIII. mendeko idazlan linguistikoekin, marko narratiboak, berriz, XIX-XX. mendeen arteko mugan hasten den eleberrigintzarekin. Idazlan linguistikoan egileak hitz egiten du. Larramendi da jakintza linguistikoa igortzen duena. Ez da horrela gertatzen Peru Abarkan ; izan ere, Mogelek bitartekari bat asmatzen du jakintza linguistikoa igor dezan : Peru. Aipatutako idazlan linguistikoetan igorritako jakintza linguistikoa errealitate soziologikoko ikasiari zuzentzen zaio ; Peruk igorritakoa, berriz, Maisu Juani. Azken batez, Larramendik euskararen erabilera hobetzeko bitarteko batzuk eman zituen. Apaiz eta, oro har, jende ikasiaren eskura euskara egokiagoa erabiltzeko tresnak jarri zituen, baina ez zuen hartzailea testura eraman. Besterik gertatzen da Mogelen idazlanean : jakintza-igorlea eta hartzailea testuan daude.

Larramendiren obraren eragilea bere idazlanaz kanpo gelditzen da ; ez horrela Mogelena. Peruren eragilea, hots, errealitate soziologikoko euskal herritar ikasia, testura eramatea erabakitzen du Mogelek : Maisu Juanek ordezkatuko du.

Peru Abarka izenburua jartzen dionean idazlanari, solaskide nagusi izango diren bi pertsonaietako baten izena hautatzen du eta, hautatzean, azpimarratzen. Peru du eredu Juan Antonio Mogelek : izenburura eramatean azpimarratu du, idazlanari eginiko hitzaurrean esan ${ }^{16}$ eta, autuari emandako garapenean erakutsiko du. Peru Abarka da Maisu Juanen maisu : ez dago zalantza-izpirik. Baina, nahiz Peru solaskide nagusia izan, nahiz "protagonista" izan, ez da idazlanaren eragilea ; izan ere, nork nor sortu ote zuen, euskararen maisu eta katedratiko den Peruk Maisu Juan izeneko bizargina ala Maisu Juan izeneko bizarginak euskararen maisu eta katedratiko den Peru ? Edo beste modu batean esanda, Basagizon Ona aurkeztea izan zen idazlanaren eragilea ala errealitate soziologikoak erakusten zituen "Maisu Juanak" eragin zuten Basagizon On horren aurkikuntza ? Peru erakusten du Mogelek Peru Abarkan, noski : bera da maisua eta berbaldiaren zati nagusia hartzen duena. Hala ere, Peru pertsonaia nagusia izanagatik, idazlaneko hitz-ore nagusiaren jabe izanagatik, berbaldia bere jakintza, bizimolde eta balore-sistema erakusteko erabili izanagatik, Mogelen asmoa ez da hainbeste Basagizon Ona erakustea nola errealitate soziologikoko "Maisu Juanen" jarrera aldatzeko aukera gogobetekoa eskaintzea. Idazlanaren eragilea ez da eredu bat aurkeztea eredu horrek sortzen duen liluragatik, baizik eta errealitate soziologikoan jende eskolatuak egiten duen euskararen erabilera aldatzeko, ikasiek hizkuntzaz egiten duten erabilera traketsa edo hizkuntzarekiko daukaten jarrera baztertzailea aldatzeko, ordezkoa ematea. Eragile hau pertsonaia bihurtzen du Mogelek : Maisu Juan izango da Peruren solaskidea.

Mogel "muy literatos" direnei zuzentzen zaie, hots, letradunei. "Clérigos, frailes, caballeros y demás" deitzen ditu Peruren eskolara eta letradun horietako bat hautatzen -Maisu Juan-ikasle horiek ordezka ditzan. Mogelek bere helburua lor dezan -jende ikasiak beren eredua Basagizon Onaren ereduagatik ordezkatuPeruren ereduak Maisu Juan asebete behar du. Peruk Maisu Juanen gogoa irabazi behar du. Irabazi zuen, idazlanaren helburuak berak eskatzen zuena beteaz.

16 - Honela dio Mogelek: “No profiere de sí voz que no sea bascongada, y al contrario corrige al barbero Maisu Juan en sus bárbaras y poco correctas locuciones. Hay interlocutores en los diálogos o conferencias de ambos, según van ocurriendo las circunstancias. Pero se ha de advertir que Peru Abarka es el único maestro y catedrático de la lengua bascongada ; sólo él habla con toda corrección" (26. or.). 
Fikziozko izakien esku utzi du Mogelek komunikazioa. Baliapide honen erabilerarekin hasten da euskal eleberrigintza berantiarraren aitzindari bihurtu ahal izateko lehen urratsa ematen. Katebegi berriarekin -eleberriarekin- izango dituen antzekotasunak eta desberdintasunak atzemateko Txomin Agirre eleberrigilearengana jo daiteke.

Txomin Agirreren eleberriek ere badute eragilerik : euskaldun guztiak dira. Honela zioen Kresa la ri egindako hitzaurrean :

“Euskaldun guztiak euskerazko gauzen irakurzaleak egin gura nituke, ta gauza astunak añ gogoz irakurten eztiralako, zerbait errezago ta gogotsuago irakurri daien artu dot ipuin bat egiteko lanbide ta asmoa". ${ }^{17}$

"Euskaldun guztiak" horien ordezkaria testuan irakurle inplizitua da. Istorioa kontatzen ari den kontalaria etengabe zuzentzen zaio bere gogoa irabazteko. Agirreren ohiturazko eleberrietan pertsonaia nagusiak irudikatuko du Peruren mundu-ikuskera eta istorioa kontatzen duen kontalariak euskaldun oro eredu horretara erakartzea bilatuko du. Agirreren eleberrietako kontalariak bere helburua lor dezan -euskaldun guztiak pertsonaia nagusiaren eredura erakarri- pertsonaia nagusiaren ereduak irakurle inplizitua asebete behar du. Pertsonaia nagusiak irakurle inplizituaren gogoa irabazi behar du.

Honenbestez, Larramendiren idazlan linguistikoetan ez bezala, funtzio konatiboak berebiziko garrantzia hartzen du Mogelen eta Agirreren idazlanetan : batean, Peruk Maisu Juan konbentzitu behar du, bestean, istorioaren kontalariak irakurle inplizitua. Baina, bada alde nabarmena Mogelek eta Agirrek hezurmamitutako igorle-hartzaileen artean. Mogelenak jakintza-igorle eta hartzaile izateaz gainera, pertsonaiak dira. Ez da beste horrenbeste gertatzen Agirreren eleberrietan : kontalariak eta irakurle inplizituak ez dute parte hartzen kontatzen diren ekintzetan. Biek daramate testura erakarri nahi duten hura, ez horregatik, modu berean.

\section{Funtzio konatiboa}

Peru Abarkak kodea goresten eta aztertzen du, baita kode horri itsatsirik bizimolde eredugarria aurkeztu ere. Ez da, ordea, geratzen azalpen horrek sorrarazitako liluran; zerbaitetarako goresten eta aztertzen du kodea : ez da bakarrik euskara hizkuntza garbia eta bete-betea, perfektua, dela adierazteko. Kodearen bikaintasuna erakutsi ahala, kode horren erabilera egiteko gonbitea etengabea da. Funtzio metalinguistikoaren ondoan funtzio konatiboak pisua hartzen du : kodea ez-ezik, hartzailea bera dakar erdigunera.

Maisuak bere irakaskuntza jasotzeko prest dagoen ikaslea eskatzen du. Peruk ikasia den ikaslea, baina euskararen alorrean eta beroni atxikirik "dagoen" baloresisteman ikastekorik baduena hautatzen du. Irakaskuntzak arrakasta izan dezan ikaslearen arreta eta interesa erakarri behar du. Maisu Juanen arreta erakartzea da Peruren jomuga.

Basarteko katedratikoa den Peru, bizargile ikasketak eginak dituen Maisu Juani zuzentzen zaio, inoiz eskolarik zapaldu ez duen Peru, Madrilen hiru titulu eskuratuak dituen Maisu Juani, euskararen ezagueran doktore eta katedratiko den

17 - Kresa la. Oarkera batzuk itzaurrea legez" in AGIRRE, Domingo (1906) : Kresa la, Florentino Elosu-ren echean, Durango, 10. or. 
Peru, euskara nahasi samarra egiten duen Maisu Juani, noiznahi euskal ondare lexikaleko hitzaren ordez erdal mailegua baitarabil.

Euskararen aberastasuna eta perfekzioa ezagutzen duen Peru, gertu dago Maisu Juani hizkuntzaren kualitate horiek frogatzeko. Une honetatik aurrera, ezinbesteko du Peruk Maisu Juanen arreta lortzea. Baita lortu ere. Ia hasiera-hasieratik azalduko da Maisu Juan Peruk erakutsitakoari abegi ona eginaz, irakasgaiak bereganatuz eta ikasitakoari aurrerantzean eutsiko diola aginduz. Bere esan eta jarrerek agerian uzten dute ez zaiola falta ikasteko borondaterik. Hala, bereganatu nahi duena buruan gordetzeko daukan eragozpena saihesteko, papera eta tintontzia atera eta, idatzi egingo du. Ikasi nahi duen hura, bere idatzizko kulturak zilegitu dion gordailura -paperera- eramatea, behin eta berriz egiten duen eragiketa da : ardandegian aita-semeak kantaturiko bertsoak edo hiztegi-zerrenda luzeak idatziz gordeko ditu

Peruk Maisu Juan "baserriko euskal munduan hezitzeko" eratzen duen egitarauan besteri ere ematen dio hitza ; izan ere, Maisu Juan eta Peruren arteko elkarrizketari beste solaskide batzuk batzen zaizkio, nola jakintza-igorle modura, hala jakintzahartzaile modura. Nahiz Peruren ekimenak, nahiz Maisu Juanen jakinminak, besteren enuntziazioa sustatuko du, dela Peruren seme Txominena, dela Peruk adiskide dituen "pranzes euskaldun" eta "kiputza"rena. Solaskide hauek jakintzaigorleak dira : Peruk hobesten duen bizimolde, ikuskera eta balore-sistemari atxikiak, laguntzaile ditu Maisu Juan hezitzeko eginkizunean. Bere ikasgaiak osatzeko bitarteko dituen solaskide hauekin batera, bada, haatik, beste funtzio bat betetzen duen pertsonaia : basoak ikusten ari direla batzen zaien apaiza, hain zuzen ere. Apaiza, Maisu Juan bezala, jakintza-hartzaile bihurtzen da : biak ikasiak izan arren, Peruren ikasgaien hartzaile izango dira. Dena den, bada alderik oinarri komun honek lotzen dituen bi ikasleen artean : ez dute, ez tratu berdina jasotzen maisuarengandik, ezta "disziplina-kopuru" berbereko jakintza ere.

Maisu Juanek gonbidatzen du apaiza beren solaskide izatera :

“Jauna, gelditu gura badau puska baten gugaz emen, enzungo ditu enzutekuak. Ona emen iru euskaldun modu : pranzesa, kiputza, ta bizkaitarra, alkar ederto aituten dabeenak. Zurtuta isten nabee hainbeste gauza jakitiaz. Asko jakin lei berorrek, baña ezditu euskerako kontubetan atrapauko" (154. or.).

Apaiza solasera batu zaien arte, Maisu Juan zen bere jakin nahia asetzeko galdetzen zuena eta Peru, berriz, erantzunekin jakin nahi hori asetzen zuena. Azken batez, apaizarekin elkartzen diren arte. Maisu Juan zen galdetzaile eta jakintza-igorleak galdera horiek erantzuten zituztenak. Alabaina, orain apaiza bihurtzen da galdetzaile eta Peru erantzule nagusi, beroni zuzentzen baitizkio apaizak galderarik gehienak, lapurtarrari eta gipuzkoarrari egindako gutxi batzuk gehituz. Apaizak bereganatzen du Maisu Juanen funtzioa solasera gonbidatzen dutenetik agurtu bitarteko tartean. Tarte horretan Maisu Juan "ikusle" soil izatera igarotzen da. Apaizak Maisu Juanen funtzioa bereganatzen duenean, ordea, ez du Maisu Juanen jarrera berdinarekin egiten. Peru eta Maisu Juanen arteko harremana ez da Peru eta apaizaren artekoa bezalakoa : ez norabide batean, ezta bestean ere. Peruk harreman-modu desberdina ezartzen du bi ikasleetariko bakoitzarekin, baita ikasleetariko bakoitzak ere berarekin. Maisu Juan erasotuz hasten da Peru. Agurtuaz bat Maisu Juanen portaera, euskara, ohiturak... salatuko ditu : ez dago, ez hitzik, ez ekintzarik, Peruren oniritzia jasoko duenik. Baserritarraren eta bizarginaren arteko harremana zeharo bertikala da : Peruk Maisu Juanek baino euskara gehiago jakiteaz gainera, zirrikiturik gabeko 
bizimolde eta balore-sistema du. Horrela, nahiz euskararen ezaguera-mailan, nahiz portaera-mailan jakintsu/ez-jakintsu harremana ezartzen du Peruk eta, laster asko onartzen du Maisu Juanek funtzionamendu-modu hori :

"Gauza batek ikaratuten nau zugan, zein ederto euskera berba egiten dozun eskolarik euki baga" (80. or.).

Besterik da Peru - apaiza harremana, elkarrenganako errespetuan oinarritutakoa baita. Ez Peruk erasotuko du apaiza, ezta apaizak ere honen maisutza onartuko daukan ezaguera linguistikoa neurtu arte. Ezaguera hori neurtzeko jartzen dion froga modurik bikainenean gaindituko du Peruk; izan ere,

“Larramendik bere ezjuan edertuago esplikauko" (154. or.),

esanaz epaitzen duenean azterketa apaizak, garaiko maisurik handienak baino hobeto erantzun izana aitortzen dio Peru baserritarrari. Orduan, garaiko maisurik handienak besteko jakintza linguistikoaren jabe dela frogatu dioenean, onartuko du apaizak Peruren ikasle bihurtzea eta, bere ikasle-egarria asetzeko galdetzea. Baina, maisu - ikasle harreman hau disziplina bakar batera mugatzen da : hizkuntzara. Agerikoa denez, ikasle bakoitzaren jakintza-gabeziak ez dira berdinak : apaizarenak hizkuntza-mailakoak dira soil-soilik, Maisu Juanenak, berriz, bizimolde eta baloresistemara hedatzen dira. Honela, Mogelek, ikasle laikoari elizgizona gehitzean, Peru Abarkari egin hitzaurrean Peruren eskolara deitu dituen ikasleak osatu ditu : hartzaile nagusia laikoa da, baina elizgizonak ere badu bere tartetxoa.

Errealitate soziologikoko ikasien ordezkari diren Maisu Juan eta apaiza bere eskolara erakarri behar ditu Peruk. Horretarako, lehen-lehenik, bakoitzak bere hutsuneak aitortu behar ditu eta hutsune horiek betetzeko nahia azaldu. Hala egiten dute, nork bere beharrak asetzera joz : Maisu Juanek Peruren ikasgai guztien premia du, apaizak, berriz, ikasgai linguistikoena bakarrik. Biak limurtzen ditu jasotako jakintzak. Hainbesteraino limurtzen ditu Peruren eskolak non, batak eta besteak, ikasle-egarria asetzearekin nahiko ez eta, irakaskuntza linguistiko horien igorle bihurtzea agintzen duten. Maisu Juanek Peru baserritarrarengandik jasotako jakintza linguistikoa bere ofiziokoei irakatsiko die :

“Ezneban sinistuko baserritar batek jakin leijala ainbeste izen, ta euskeria zala ain aberatsa bere berbeetan. Nik ezin artu neiz buruz izen guzti orreek illabetian bere. Iminiko ditut paperian, erakusteko beste nire opizijokuai" (85. or.).

Bere ofiziokoei ez-ezik, baita bere herriko apaizari ere :

“Bati baño geijagori enzun deutsat baserritarretan daguala euskera garbija ; Gaztelan izan garianok ta uri barrubetakuak erdera askogaz nastetan dogula euskeria. Zuri enzuten deutsudazan izen neuk eztakidazanak iminiko ditut paperian, euskera ondo berba egiteko. Gure erriko kuriari enzun deutsat buruba ausita bere ezin dabela sermoe bat euskera ondo imini. Nik erakutsiko deutsadaz zuri ikasten deutsudazanak" (80. or.).

Ez zen oker ibiliko Aita Larramendi apaizen sermoietako euskara-maila eskasa salatzen zuenean. Maisu Juanek ere badaki, bere herriko apaizak berak aitortu baitio sermoia euskara duinean prestatzeko zailtasunak dituela. Aita Larramendik eragozpen horiek gaindi zitzaten egin bazituen bere gramatika eta hiztegia, Maisu Juanek ere bere laguntza eskainiko du : sermoietako euskara hobetu dezan Perurengandik ikasitakoa irakatsiko dio bere herriko apaizari.

Peru Abarkako beste jakintza-hartzaileak, apaizak, Peruren maisutza onartu eta, aurrerantzean, baserritar "erderagabetuengandik" ikasiko duela euskara agindu ostean, 
“Eta Jangoikuak naiba, emendi aurrera artuko dot ardura andi bat baserritar ta beste nekezale erderabagakuetati euskeria ondo baño obeto ikasteko" (164. or.),

bereganatutako jakintza linguistikoaren igorle bihurtzeko asmoa azaltzen du. Gainera, iragartzen duen igorletza-esparruak adierazten duenez, Maisu Juanenak osatzera dator :

“Gizonak, ez bururik ausi geijago. Ezdago geijago zer enzun. Orain niri jagot imintia erderaz zuben irakatsija.

Orra emen eskribidu ta erderatuta zubek irakatsi deustazuzan berba edo izenen azterren edo esplikazinuak. Irakatsi egidazuz geijago jakin daijen gaztelar ta erdaldun guztiak zelangua dan gure euskeria" (160-161. orr.).

Hala, apaiz eta Maisu Juanen ofiziokoengana ez-ezik, erdaldunengana ere helduko dira Peruren irakaskuntzak. Peruren ikasleek barruti desberdinetan zabalduko dute ikasitakoa ; apaizak, gainera, erdara-izpirik ez dakien Peruk zeharo eskuragaitza duen eskolan : erdaldunen artean.

Idazlanaren helburua argi asko adierazi zuen Mogelek : jende ikasia Peruren eredura erakarri. Badirudi helburuaren lorpenerako Peruren ereduak "muy literatos" horiek liluratu behar dituela. Berez, idazlanaren jomugak beharrezko zuen eskakizuna beteaz, liluratu zituen "muy literatos" horien ordezkariak, apaiza eta Maisu Juan jakintza-hartzaileak. Baina, ordezkari horiek konbentzitu zituen bezala, heldu ote zen barne-hartzaile hauek jarraitzen duten prozesua bizi izatera deituta zeuden kanpo-hartzaileak konbentzitzera ? Ordezkari horien bidea egin ote zuten Peruren eskolara gonbidatutako "muy literatos"ak ? Bere izateko arrazoi nagusia kanpo-hartzaile hauek konbentzitzean duen arren Peru Abarkak, bada motiborik azken jomuga honen lorpena zenbateraino eskura zezakeen galdetzeko. Motibo horien artean ez da txikiena Mogelek eredua eraikitzeko, gizaki itxura erro-errotik kendu izana Peruri.

Mogelek bere ahotsa ordezkatzeko sortzen du Peru. Gabeziarik gabeko jakintzaigorle honen bidez, gainontzeko pertsonaia guztien gainetik dagoen paradigma honen bidez, eredu hutsa den bitarteko honetaz baliatuz, helaraziko du Mogelek bere eredu propioa. Baina, hain eredu eredugarriari bizitza eman nahiak mugak estutzen dizkio eta muga hauek estutu ahala, zabalduz doaz ereduari aurkajartzen zaiona irudikatzeko ahalbideak ; izan ere, azkenean, Peruri gizaki itxura kendu ahala, gizaki itxuran irabaziz doa Maisu Juan. Zirikadak, salaketak, edo sustrairen bat duten usteak, Maisu Juanen ahotsak jasotzen ditu eta, horrela, "desegokiak" liratekeen pentsamenduen azalpenetik babesten da Peruren ahotsa. Ahotsen arteko joko honen azterketa xehea saihestuz, pasadizo baten azalpenak balio beza aditzera eman nahi dena argitzeko. Adibidez, deigarri samarra suertatzen da nola, Maisu Juanen euskaramaila hain zorrotz eta gogor salatu duen Peruk, ez duen iruzkin txikienik ere egiten apaizak euskararen gainean ezaguera sakonagoa ez izateagatik. Zinez, apaizak ez darabil Maisu Juanen euskara traketsa, baina, agerian uzten du bere eliztarrek beste jakiteko lanik ez duela hartu. Mogelek apaiza Peru baserritarraren ikasle bihurtu du, egoera zail horretan jarri du, ez du nahi izan, ordea, ereduak sala zezan. Mogelek Peruren ahotsa babestu egiten du esku-eskura zeukan zirikadatik eta, Peru babestean, baita bere burua ere. Hala izan dadin, Peruk apaizaren "ahulezia" salatzea saihesten da : ez du, ezta iruzkinik txikiena ere egingo. Mogelek, haatik, ez du etsi zirikadarik gabe : Peruren ahotsean jartzea komeni ez dena esateko dauka Maisu Juan eta honengana joko du apaizak eztenkada jaso dezan : 
"Ni ez-eze, abade jauna bere lotsatuta juan da ikusirik zubek dakizuna..." (167. or.).

Mogelek, ondo dagoena eta ez dagoena bereizteko eta epaitzeko zalantza-izpirik ez duen Peru babestu eta, Maisu Juanengana jo du apaizaren euskararen alorreko ezaguerak urriegiak izatea salatzeko. Maisu Juan bitarteko bikaina du Mogelek : batetik, Peru ereduaren babesle da ; bestetik, ereduaren eragile. Azken batez, Mogeli babesa emateaz gainera, erakutsi nahi dituen gaiak erakusteko aukera sorrarazten dio, salatu edo argitu nahi dituen ideiak argitzeko bitarteko duelako : Maisu Juanek planteatu eta, Mogelek, Peruren bidez, planteatutakoaren gaineko "pentsamendu zuzena" ezarri.

Eginkizun-banaketa honetatik sortuz doazen pertsonaien erretratuak ere desberdinak dira. Mitxelenak zioen bezala :

“No resultará sorprendente que también aquí, como suele ocurrir en estos libros con moraleja, el lector se sienta mucho más atraído por Maisu Juan que por Peru y su ejemplar familia. Estos son demasiado buenos para ser verdaderos, en tanto que la figura del barbero -con su vanidad, sus picardías y su saber formado de palabras retumbantes- no habría resultado tan humana si el autor no le hubiera mirado con íntima y comprensiva simpatía". ${ }^{18}$

Hala da. Antzeko zerbait gertatzen da Txomin Agirreren eleberrietan : Garoako Joanes pertsonaia eredugarriegia da egiazkoa izateko. Peru eta Joanes jakintsuak, ziurretan ziurrenak, ahuleziarik gabeko izaki irmoak, eredu hutsak, urrutiratu egiten dira gizakiarengandik.

Peruren eredura erakartzea izanik jomuga idazlanak, uste izatekoa zen Peruren irudiak Maisu Juanenak baino erakargarriago suertatu behar zuela hartzailearentzat, batak bestea ordezkatzeko irudikatutakoak baitira. Alabaina, badirudi Maisu Juanen irudia ateratzen dela garaile eta Perurena galtzaile ; alegia, Maisu Juanen erretratua Perurena baino erakargarriago zaiola irakurleari. Ustekabeko emaitza honek esanarazi zion Ibon Sarasolari,

"zeren ez baititu Mogelek tesisaren beharretara pertsonaiak makurtzen. Aitzitik bere dohain literarioez baliaturik, elkarrizketa berberaren barne estrukturak eskatzen duen arauaz gauzatzen ditu haik, nahiz honekin tesisa arriskuan jarri. Horrela maisu Juan, tesisaren arauaz "gaiztoa" dena, pertsonaiarik egiazkoena eta helduena da, Peru abstrakto samarra baino areago eta, tesisaren kontra, haren alde jartzeko oin ematen dio irakurleari. ${ }^{19}$

Jakina, ukaezina da tesiaren arabera Maisu Juan dela "gaiztoa". Tesi hori bezain ukaezina da pertsonaia "gaiztoa" dela Peru Abarkako pertsonaiarik egiazkoena. Pertsonaiarik egiazkoena izatearen efektua ere ez zen lortuko "si el autor no le hubiera mirado con íntima y comprensiva simpatía". Begirada-modu honen ondorioz, "haren alde jartzeko oin ematen dio irakurleari". Halere, ezaugarri hauek erakusten dituen Maisu Juanek, nire ustez, ez dio eskuetatik ihes egin Juan Antonio Mogeli bere bizitza propioa bizi izateko : Mogelek Peru Abarka idaztean zuen plangintzari erantzuten badio Peruk, baita Maisu Juanek ere. Gakoak helburuan egoten jarraitzen du : jende ikasia Peruren eredura erakarri.

Autura jo zuen Mogelek bere tesia azaltzeko, eleberria hautatu zuen Txomin Agirrek bere tesiak agertzeko. Genero desberdinez baliatu ziren, baina, nola biak tesiak testura eraman izanak, hala azaleratzen duten mundu-ikuskeran atzematen diren loturak, ireki dezake erkaketarako biderik eta argibideren bat eman

18 - MICHELENA, Luis (1960) : Historia de la Literatura Vasca, Ediciones Minotauro, Madrid, 109. or. 19 - SARASOLA, Ibon (1971) : Euskal literaturaren historia, Lur editoriala, Donostia, 35-36. orr. 
pertsonaia nagusiaren itxuratzearen inguruan. Txomin Agirrek bere eleberrietako "gaiztoak", Mogelek Maisu Juan ez bezala, modu esperpentikoan taxutzen ditu eta, biziarazten dien istorioaren amaieran, zigortu egiten ditu. Hala gertatzen da Kresa la ko Indianoarekin edo Ga roa ko Juan Andres eta bere familiarekin. Txomin Agirreren eleberrietako pertsonaia nagusiek hobesten duten bizimolde eta baloresistematik urrundu eta, beste bizimolde eta balore batzuei atxiki izanagatik kondenatzen dira tratamendu horretara.

Jadanik aditzera eman denez, hartzailego desberdinari zuzentzen zaio bata eta bestea. Mogelek Peruren eskolara "clérigos, frailes, caballeros" deitzen ditu, Agirrek bere aldetik, euskaldun guztiak deitzen ditu Kresala ko edo Garoako "pertsonaia nagusien" eskolara. Ikasien ordezkariak Peru Abarkan Maisu Juan eta apaiza dira, ordezkari nagusia, Maisu Juan, bigarren mailakoa, apaiza : hauek erakarri behar ditu Peruk. Agirre, berriz, euskaldun guztiei zuzentzen zaie eta euskaldun guzti hauen ordezkaria testuan, irakurle inplizitua da. Irakurle inplizitua erakartzen saiatzen da Agirreren eleberrietako kontalaria. Horretarako zuzentzen zaio behin eta berriz kontalaria irakurle inplizituari : baliapide desberdinak erabiliz irakurle inplizituaren borondatea irabazten ahalegintzen da kontalaria. Agirreren eleberrietako kontalariak pertsonaia gaiztoak -Indianoa, Juan Andres,...- karikatura huts bihurtu eta, etengabe mezprezatzen ditu. Ez du berdin jokatzen irakurle inplizituarekin : berau limurtzea bilatzen du, helarazi nahi dizkion mezuei abegi ona egin diezaien.

Mogelek bere helburua erdiesteko -jende ikasia Peruren eredura erakarri- ezin ditu zeharo karikaturizatu ordezkariak : kontu handiarekin zaindu behar duen alderdia da, zeren Maisu Juan "egiazko" hori gabe, "gaitz guztien bilduma" zatekeen Maisu Juana sortu izan balu, nola erakarriko zituen ikasiak ? Mogelek errealitate soziologikoko ikasiak Peruren ereduaren paregabetasunaz konbentzitzea ez-ezik, beharrezkoa du sinesgarritasun-mailaren bat duten ikasien ordezkariak testuratzea eta gutxieneko duintasun-maila batekin tratatzea; izan ere, errealitate soziologikoko ikasiak identifikazio-punturen bat behar du ikasi horrekin, mailaren batean bere burua bertan erretratatua ikusi. Begi bistakoa dirudi, erakarri nahi den hura, sinesgarritasun eta duintasun-maila batekin tratatu behar dela. Bestela, nola erakarri ?

Peru bada euskal ohiturazko eleberrietan biziko diren baserritar eredugarrien anaiarik zaharrena, ${ }^{20}$ Maisu Juan, ordea, ez da baserritar horien eredutik urrutiratzen direnen anaia zaharrena : ez da Ga roa ko Joanesen seme edo iloba ez eredugarrien anaia zaharrena. Ez da eta ezin izan zitekeen ; izan ere, Mogelen idazlanaren barne-hartzaileak idazlaneko pertsonaia batekin, Maisu Juanekin, bat egiten du. Ez da beste horrenbeste gertatzen Agirreren obran : barne-hartzailea ez da pertsonaia bat. Agirreren eleberrietako pertsonaia ez eredugarriak ez bezala, Maisu Juanek bi funtzio bereganatzen ditu : pertsonaia ez eredugarria eta pertsonaia eredugarriaren irakaskuntzaren hartzailea. Funtzio bikoitza izanaz, ezin izan zitekeen funtzio bakarra bereganatzen duten Agirreren eleberrietako pertsonaia ez eredugarriak bezalakoa. Honenbestez, tesia ezin aurkez zitekeen modu berean : Mogelek tesia ikasiei zuzentzen die eta ikasiak berak parte hartzen $\mathrm{du}$ "istorioaren" garapenean ; Agirrek tesia euskaldun guztiei zuzentzen die eta kontatzen duen istorioan ez dute parte hartzen.

20 - Honela zioen Lasagabaster irakasleak: “Mogel'ek asmatutako pertsonaia ez da Rousseau'renaren anaia ttipia, baizik ehun edo urte beranduago euskal ohiturazko nobelaren mundu idilikoan emeki biziko diren baserritarren anaia zaharrena", op. cit., 84 . or. 
Azken batez, egitura-modu desberdinak aurkezten dituzte. Ondorioz, egitura bakoitza osatzen duten elementuek funtzio desberdina betetzen dute batean eta bestean. Agirreren eleberrietan kontalari batek istorioa kontatzen dio behin eta berriz aipatzen duen irakurle bati. Kontalariak pertsonaia "on" eta "gaiztoak" sortu eta, hauen arteko harremanen berri ematen dio irakurle horri. Autuaren egitura darabilen Peru Abarkan ez dago kontalari baten bitartekotasunik. Inoren bitartekotasunik gabe hitz egiten dute solaskideek. Honela, Peruren esanen hartzailea Maisu Juan da zuzen-zuzenean. Baina, Agirreren istorioen hartzailea irakurlea da. Biek, Agirreren eleberrietako kontalariak eta Peru Abarkako Peruk, hartzailea erakartzea bilatzen dute : lehenak aurkezten dizkion pertsonaia "onen" eredura erakarri nahi du, bigarrenak berak zuzenean irudikatzen duen eredura. Laburbilduz, eleberri horietan istorioa igortzen duena eta istorioaren hartzailea ez dira, aldi berean, pertsonaia eta, horrenbestez, ez dute parte hartzen ekintzetan. Autuan, berriz, jakintza-igorlea eta jakintza-hartzailea pertsonaia dira eta beraiek dira ekintzetan parte hartzen dutenak, nahiz eta egindako ekintzak ia-ia esanaren barruti soilera mugatu : esanek irensten dute ekintzen lekua.

\section{Ondorio gisa}

Larramendiren hiztegia edo gramatika idazlan linguistiko hutsak dira. Bere asmoa agerian utzi zuen : hizkuntza goretsi eta hizkuntza horren erabilera hobea bideratzeko bitarteko batzuk eskura jarri. Euskara hizkuntza duina dela, hizkuntza landutzat jotzen diren horien mailan dagoela frogatzen die bere idazlanen kanpohartzaile nagusi dituen elizgizonei eta, aldi berean, beren eliztarrekin dituzten harremanetan euskara egokiagoa erabiltzeko aukera emango dien tresnak eskaintzen dizkie. Mogelek ere, idazlan linguistikoa egiten du : hizkuntza goresten eta aztertzen du. Horretarako, ordea, jakintza linguistikoa igorri eta jasoko duten pertsonaiak irudikatzen ditu : pertsonaiok ordezkatzen dituzte jakintza linguistikoaren kanpo-igorlea eta kanpo-hartzailea. Jakintza linguistikoaren igorletzarako euskararen ezagueran adituenentzat zeukan hartara jo zuen : Basarteko katedratikoarengana. Ordezkari honek eredu bat igorri zuen, hizkuntzaren barrutia gainditzen zuen eredua, hain zuzen ere. Eredu-igorle honek nahitaezko du bere ikaslea bereganatzea : idazlanaren muinak berak eskatzen du ; izan ere, eredu batera (hizkuntza, bizimolde, balore-sistema) erakartzea baitu jomuga.

Agirreren idazlanak ez dira idazlan linguistikoak, nahiz eta kezka linguistikoak azaleratzen dituzten bai paratestuan, ${ }^{21}$ baita testuan bertan ere. Agirrek, Mogelek bezala, besteri ematen dio hitza : kontalariaren ahotsaren bitartekotasunaz baliatuko da istorioak kontatzeko. Kontalariak kontatutako istorio horietan pertsonaia nagusiak irudikatzen du eredua : pertsonaia nagusi hori da euskararik, bizimolderik eta balore-sistemarik eredugarriena duena. Badira, halaber, eredu horrek irudikatzen dituen baloreei uko egiten dietenak. Pertsonaia nagusi hauen egitekoa izan, bada, beren eredutik kanpo bizi direnak beren eredura erakartzea, baina egiteko honetan arrakasta nahiz porrota jaso, ez du eraginik idazlanak helarazi nahi dituen baloreetan, eredutik kanpo bizi direnak ez direlako eredura erakarri

21 - Honela dio Kresala ri eginiko hitzaurrean :“Inoregaz aberasturiko izkuntz asko dakusguz arro ta lerden, alderdi guztietan euren buru apainduak erakusten; atera daiguzan guk be geure etxe barruko aberastasunak, apaindu daigun aldogun aiñan euskerea ta erakutzi daiegun erbesteko arerio ta erritar erbestetuai eztala illteko zorian bizi ta eztala gañera eurak uste daben legez illgarria. (...). KRESALAda nik euskerearen alde gaur dakartan ondar aletxoa" (10. or.). 
behar direnen ordezkari. Eredura erakarri behar direnak istorioan paperen bat betetzen duten pertsonaietatik kanpo daude.

Marko zientifiko soilaren "seriotasun" eta "astuntasunean" gelditu zen Larramendi, marko zientifikoaren "seriotasuna", "erakargarri" eta "jostari" izatearekin nahasi zuen Mogelek, "ta gauza astunak ain gogoz irakurten eztiralako, zerbait errezago ta gogotsuago irakurri daien" idazten ditu Txomin Agirrek bere irakurgaiak. ${ }^{22}$ Ibilbide honetan idazlana zientziaren barrutia lehertuz doa, zientzia linguistikoa tartea galduz doa, marko narratiboa, berriz, haziz.

Marko zientifikoaren mugen barnean gelditu zen Larramendiren aurrean, Mogelek jakintza linguistikoa emateko, marko zientifikoaren mugak hautsiz, marko narratibora jo zuen. Marko honetaz baliatuz gauzatzen duen idazlanean jakintza linguistikoari bizimolde eta balore-sistema jakin bat itsasten dizkio. "Gehigarri" hauek bizi-iraupen luzea eskuratuko dute : Peru Abarka idatzi zenetik XX. mendearen bigarren erdiraino garatzen den eleberrigintzako pertsonaia nagusiak Peruren eskolan hezitakoak dira. XX. mendearen bigarren erdian ere jarraitzen dute, baina beste eskola batzuetan hezitakoen ondoan, gero eta leku apalagoa dute. Baina, Peruren ereduak bakarrik iraungo du ; izan ere, Peruren eskolara erakarri nahi den ikasi laikoak, Maisu Juanek, ez du jarraipenik izango.

Beraz, euskal letren ibilbidearen ardatzean Peru Abarka kokatzean, honako bereizgarri hauek aipagarri dira : batetik, jakintza linguistikoa emateko fikziozko izaki batera jotzea, bestetik, fikziozko izaki horrek sortutako eskolak bizi-iraupen luze samarra eskuratzea eta, azkenik, eskola horrek erakarri duen ikasle ikasi laiko bakarra Maisu Juan izatea. Peruren eskolari jarraipena emango dioten eleberrigileak "irakurleari" zuzentzen zaizkio eta irakurle oro dute ikasle. Ikasle ikasi laikoaren erretratu bakarra Maisu Juanena da, nahiz eta bera ez izan Peruren eskola jarraitu beharko lukeen "gaizto" bakarra ; baina "gaizto" hauek erretratatzen diren arren, ez dira ez pertsonaia ikasiak, ezta eleberri horietako kontalariaren istorioaren hartzaileak ere ; ez dira horiek kontalariak erakarri behar dituenak : Peruren eskolaren jarraitzaileei dizdira handiagoa emateko erabiltzen diren bitartekoak dira. Maisu Juan, ordea, bada Peruren jakintzen hartzailea eta jasotako ikasgaiek konbentzitu behar dutena. Horrela bakarrik lor dezake Mogelek bere azken jomuga : Maisu Juanek bizi izandako prozesua biziaraziz errealitate soziologikoko Maisu Juanei. Maisu Juanen aldaketak efektu biderkatzailea lor dezala nahi du Mogelek : Peruk Maisu Juan bereganatzean, beregana ditzala Maisu Juanen erretratuak biltzen dituen guztiak, berarekin identifikatzen diren guztiak. Peru Abarkan nagusi den funtzio metalinguistikoaren izateko arrazoia funtzio konatiboaren baitan dago : Peruren irakatsiak alferrikakoak dira ez badu lortzen Maisu Juan erakartzea eta ariketa honek efektu biderkatzailerik ez badu eragiten. Horregatik, egileak, Mogelek "con íntima y comprensiva simpatía" begiratuko du Maisu Juan : ezin saihets dezakeen funtzio konatiboaren eskakizuna da. 